
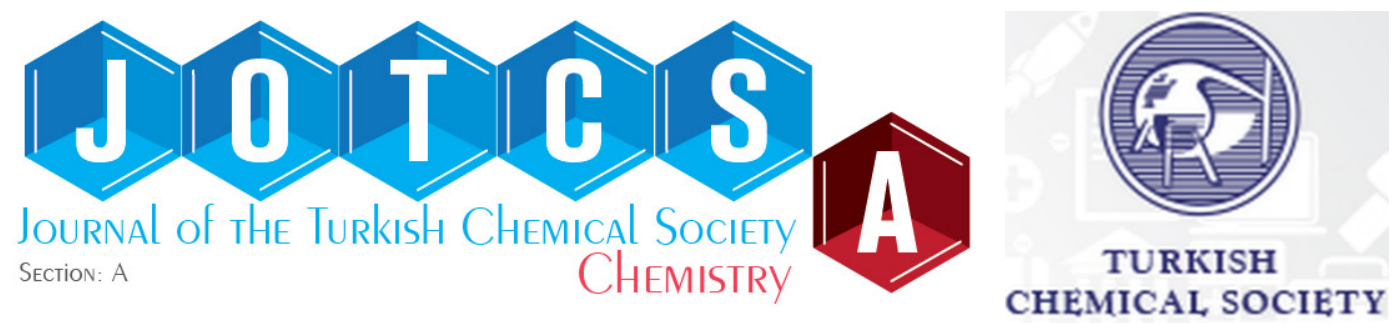

\title{
Complementary Use of Raman and $\mu$-XRF Spectroscopy for Non- destructive Characterization of an Oil Painting by Turkish Painter İbrahim Çallı
}

\author{
Özden ORMANCI $\triangle \mathrm{D}$, Meriç BAKILER \\ Mimar Sinan University of Fine Arts, Istanbul, Turkey.
}

\begin{abstract}
The aim of the present work was to investigate the pigments used in oil painting "in the park" created in the first half of the $20^{\text {th }}$ century, by Turkish painter and academician ibrahim Çallı (18821960). The non-destructive analyses were performed with a combination of $\mu$-XRF and Raman Microscopy. Obtained results revealed following pigments on the investigated painting: Zinc white $(\mathrm{ZnO})$, zinc yellow $\left(\mathrm{K}_{2} \mathrm{O} \cdot 4 \mathrm{ZnCrO} \cdot 3 \mathrm{H}_{2} \mathrm{O}\right)$, chrome yellow $\left(\mathrm{PbCrO}_{4}\right)$, strontium yellow $\left(\mathrm{SrCrO}_{4}\right)$, ultramarine $\left(\mathrm{Na}_{7} \mathrm{Al}_{6} \mathrm{Si}_{6} \mathrm{O}_{24} \mathrm{~S}_{3}\right)$, prussian blue $\left(\mathrm{Fe}_{7} \mathrm{C}_{18} \mathrm{~N}_{18}\right)$, hematite $\left(\alpha-\mathrm{Fe}_{2} \mathrm{O}_{3}\right)$, cadmium red $(\mathrm{CdSe})$, barite $\left(\mathrm{BaSO}_{4}\right)$, and carbon black. There is a great lack of knowledge about the materials used in Turkish painting and this non-destructive study provides the first systematic investigation into Çallı's palette.
\end{abstract}

Keywords: Micro-Raman, micro-XRF, pigment characterization, non-destructive analyses, Turkish painting.

Submitted: December 20, 2020. Accepted: March 11, 2021.

Cite this: Ormancı Ö., Bakiler M. Complementary Use of Raman and $\mu$-XRF Spectroscopy for Nondestructive Characterization of an Oil Painting by Turkish Painter İbrahim Çallı. JOTCSA. 2021;8(2):491500.

DOI: https://doi.org/10.18596/jotcsa.842525.

*Corresponding author. E-mail: meric.bakiler@msgsu.edu.tr.

\section{INTRODUCTION}

There was a widespread assumption that art and technology were notions opposite to each other. However, during the recent years, a great awareness has been created across several disciplines that modern science and technology are crucial for a better insight into art and cultural heritage $(1,2)$. The characterization of pigments on artworks is the major interest by reason of providing detailed historical and technological information. The identification of the chemical composition and degradation products of the pigments used, provide a remarkable contribution to the conservation method to be employed $(3,4)$. This would also allow the detection of forgeries by the detection of anachronistic pigments due to well establishing chronology of most pigments(5). However, pigment analysis can be a challenging problem because of the extremely limited sampling of works of art. In such cases, the non-destructive techniques, which can be applied on the object itself, is obviously mostly desirable. In a detailed analysis of the different possible techniques for pigment analysis, it is reported that Raman microscopy is the best single technique for this purpose due to its specificity, sensitivity, spatial resolution, and providing spectra which are free from interference by the surrounding materials(69). Many authors have previously reported Raman studies of oil painting mainly focused on the palette composition and pigment admixtures and in some cases on the degradation of pigments(1017). However, to the best of our knowledge it is not very likely to find scientific data on the Turkish paintings, except a work investigating a Feyhaman Duran painting, the contemporary of Ibrahim Çallı(18).

In parallel with the westernization policies of the Ottoman Empire, a new style of art entered to Ottoman visual culture. The most important event regarding the history of Turkish painting was the foundation of Sanayi-i Nefise Mektebi (1882) in İstanbul (today, Mimar Sinan Fine Arts University), which was founded by Osman Hamdi Bey who 
received education of painting in Paris. A group of young artists who graduated from the Academy of Fine Arts went to study abroad after the Second Constitutional Revolution. They returned to the empire with the beginning of World War I in 1914 and despite training in academic style, they started painting with an impressionistic palette. This younger generation rebelled against the academism of their teachers and introduced a new concept of painting to Turkey(19-21). İbrahim Çall $(1882-1960)$ is one of best known member of the group and has a more active position than the others. He is considered to be the pioneer of the Impressionist trend in Turkey, such that the group is also known as the "Çallı Generation" $(20,21)$.

The paper here presented intends to display the analytical characterization results of the Çallı's pigment palette which he used on the painting "in the park" $(75 \mathrm{~cm} \times 60 \mathrm{~cm})$. It is understood from the artist's signature that the painting was created before 1934, when the surname law came out. Raman and $\mu$-XRF spectrometers were used with the aim of characterizing the pigments used. For the first time in this study, an oil painting by a Turkish painter was analyzed non-destructively considering the importance of the painting and it is also crucial to state that, this work is the first to investigate a Çallı painting, regarding the pigment palette.

\section{MATERIALS AND METHODS}

All the studies were performed non-destructively using the facilities of Central Research Laboratory (MerLab), functioning under Materials Research Center for Cultural Property and Artworks in Mimar Sinan Fine Arts University, İstanbul, Turkey.

For elemental characterization, a Bruker ARTAX 800 micro X-Ray Fluorescence spectrometer $(\mu$ XRF) with molybdenum source, at an electric accelerating potential of $40 \mathrm{kV}$ and a current of $600 \mu \mathrm{A}$ was used. The measuring head which consists of a central unit containing a Peltiercooled silicon drift detector, the laser spot and the
CCD camera, allowed us to focused on the different spots of the sample. Each spectrum was collected during 60 s and evaluated by ARTAX software.

Raman microscopy measurements were made with a Bruker SENTERRA Dispersive Raman spectrometer, which is equipped with an Olympus confocal microscope mounted onto a crane (Figure 1 ). In this study, 20x and 50x magnification objectives were employed to focus the $785 \mathrm{~nm}$ laser beam onto the samples. The irradiating laser power (1-50 $\mathrm{mW})$ and the exposure time has been changed during the study. The analysis were performed directly on the painting, and the signals recorded by a TE-cooled CCD detector. The band intensities are defined as vw: very weak; w: weak; m: medium; s: strong; sh: shoulder throughout the text.

Since, the analyses were based on the use of nondestructive techniques, no samples were removed from the painting. After the visual inspections on the artwork, the colors and points to be analyzed were selected considering their homogeneity and the analytical reproducibility, and they were shown in Figure 2.

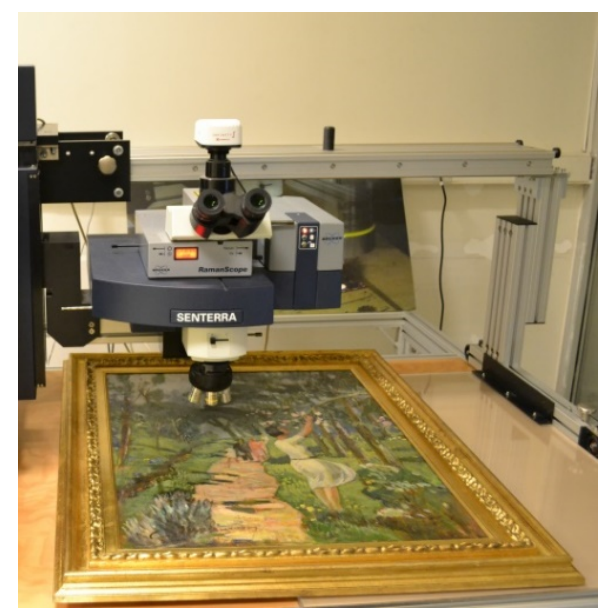

Figure 1. The raman spectrometer, which was used in this study, equipped with a confocal microscope mounted onto a crane. 


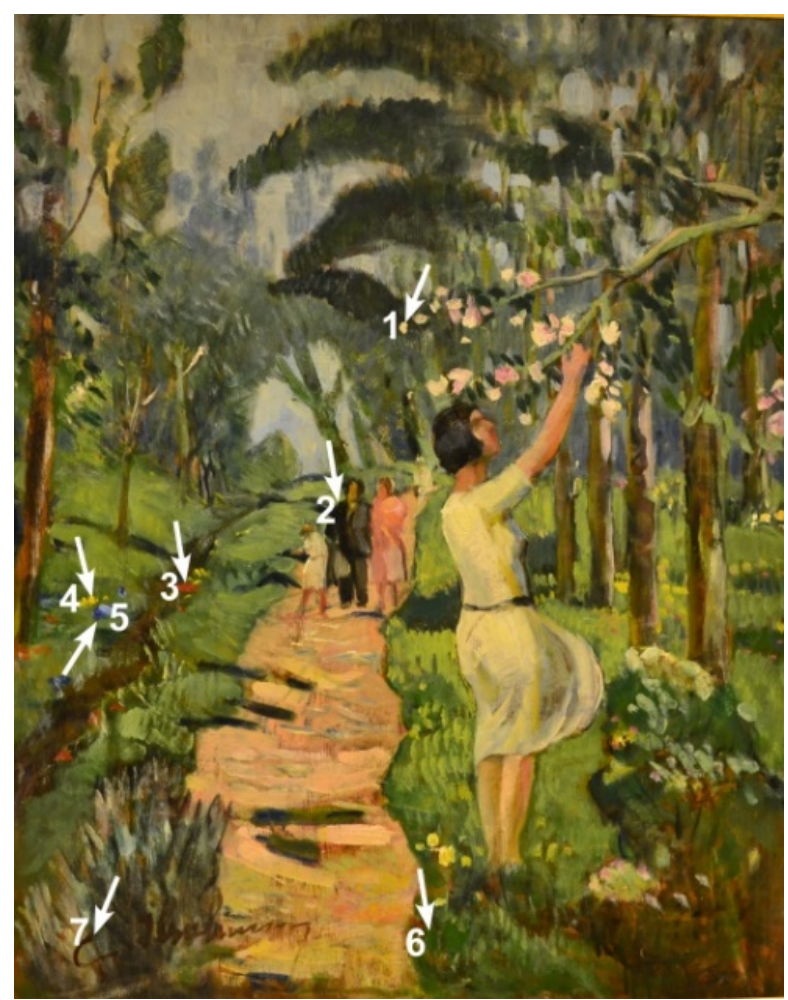

Figure 2. ibrahim Çallı's oil painting "in the park" $(75 \mathrm{~cm}$ x $60 \mathrm{~cm})$ and the points from which Raman and XRF spectra were collected.

\section{RESULTS AND DISCUSSION}

As shown in Figure 3, paint layers were applied directly onto the rough surface of a wooden panel support, no preparation layer was laid on.

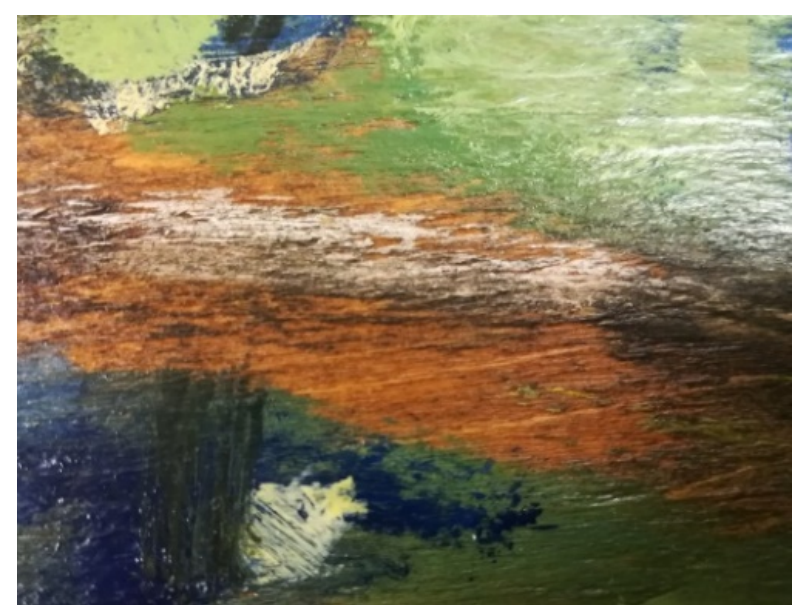

Figure 3. Photograph showing the Wooden panel support.

XRF analysis of the Spot 1 shows three elements which can be related to white color: zinc and lead. On the other hand, Raman analyses were carried out from a significant number of points and only one measurement yield a useful Raman spectrum (Figure 4) since zinc white is a poor Raman scatter(22). This spectrum confirmed the application of zinc white with the characteristic bands at 99, 320 and $435 \mathrm{~cm}^{-1}(23)$. However, white paint is likely a mixture of lead white and zinc white.

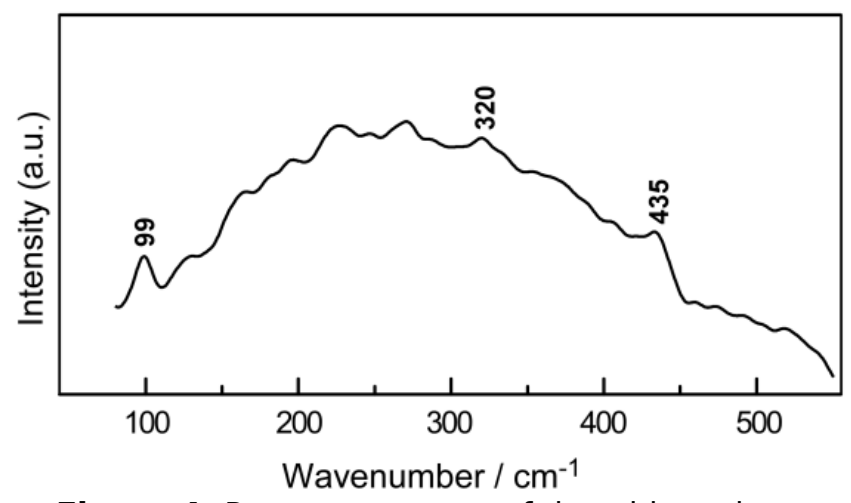

Figure 4. Raman spectrum of the white color (Spot 1).

Figure 5 shows the Raman spectrum of the green color, Spot 6 . The green pigment was detected to be not a green chromophore but a mixture of Prussian blue $\left[\mathrm{Fe}_{4}\left[\mathrm{Fe}(\mathrm{CN})_{6}\right]_{3} \cdot \mathrm{xH}_{2} \mathrm{O}\right]$ and chrome yellow $\left(\mathrm{PbCrO}_{4}\right)$. The intense peak at $2153 \mathrm{~cm}^{-1}$ and weaker bands at 2091, 534, and $277 \mathrm{~cm}^{-1}$ clearly indicate the presence of blue, while the band at $841 \mathrm{~cm}^{-1}$, due to $\mathrm{CrO}_{4}{ }^{2-}$ stretching, is assigned to chrome yellow $(3,24,25)$. Prussian blue is reported as a compatible pigment which can be used in mixtures with lead chromate to produce green color and many studies have shown its predominant application as a blue pigment used to achieve green hues(22,24,26-28). Furthermore, the spectrum shows a band at $987 \mathrm{~cm}^{-1}$ which is 
caused by barium sulfate $\left(\mathrm{BaSO}_{4}\right)$ and its presence may be related to Prussian blue since barium sulfate is reported to be detected in Prussian blue widely(29). It may also be intentionally added as an extender or a white pigment. The analysis of $X R F$ spectra confirmed these findings and revealed the presence of $\mathrm{Zn}, \mathrm{Fe}, \mathrm{Cr}, \mathrm{Ba}, \mathrm{Pb}$, and $\mathrm{S}$. In addition to these elements $\mathrm{Ca}$, which may be suggesting the application of a small amount of calcite $\left(\mathrm{CaCO}_{3}\right)$, was also detected.

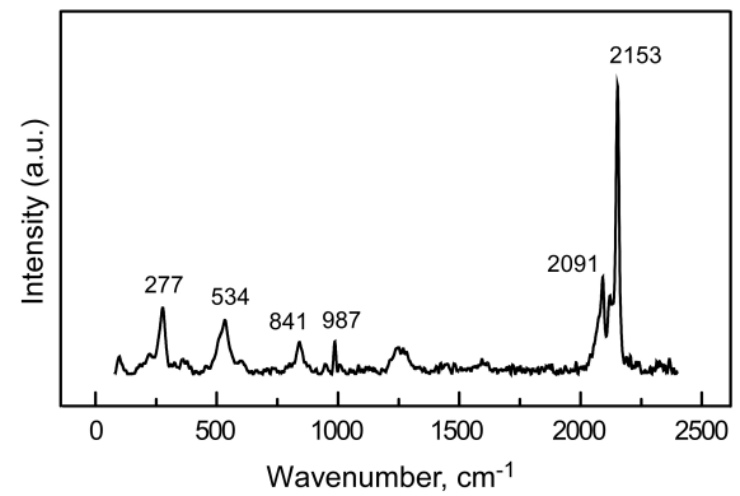

Figure 5. Raman spectrum of the green color (Spot 6).

Regarding the yellow color (Spot 4), characteristic Raman bands of zinc yellow at 114 (vw), 162 (vw), $346(\mathrm{~m}), 358$ (sh), 412 (vw), 776(vw), 874 (vs), 894 (sh), $942(\mathrm{~m}) \mathrm{cm}^{-1}$ were detected (Figure 6) $(25,27,30)$. Zinc yellow was first synthesized in about $1800 \mathrm{~cm}^{-1}$ but it has not been used as a pigment until the second half of the 19th century. The basic zinc chromate has the composition $4 \mathrm{Zn}(\mathrm{OH})_{2} \cdot \mathrm{ZnCrO}_{4}$, while most modern yellows are of the $\mathrm{K}_{2} \mathrm{O} \cdot 4 \mathrm{ZnCrO}_{4} \cdot 3 \mathrm{H}_{2} \mathrm{O}$ composition(31-33). In this study, detection of $\mathrm{K}$ in XRF spectrum of the yellow color, indicating the application of a pigment having zinc potassium chromate hydrate composition. Besides these elements mentioned above, the XRF analysis revealed the presence of $\mathrm{Sr}, \mathrm{Pb}, \mathrm{Fe}, \mathrm{Ba}$, and $\mathrm{S}$ in Spot 4 . The high amount of $\mathrm{Sr}$ detected in yellow area can be considered as an important clue indicating the application of strontium yellow (Strontium chromate, $\mathrm{SrCrO}_{4}$ ) pigment, although it was not detected in the Raman spectra. The presence of $\mathrm{Pb}, \mathrm{Fe}, \mathrm{Ba}$ and $\mathrm{S}$ may not be unambiguously related to the yellow pigment, rather may be indicating the underlayer pigment, which we believe is a mixture of Prussian blue and chrome yellow as it is identified on Spot 6.

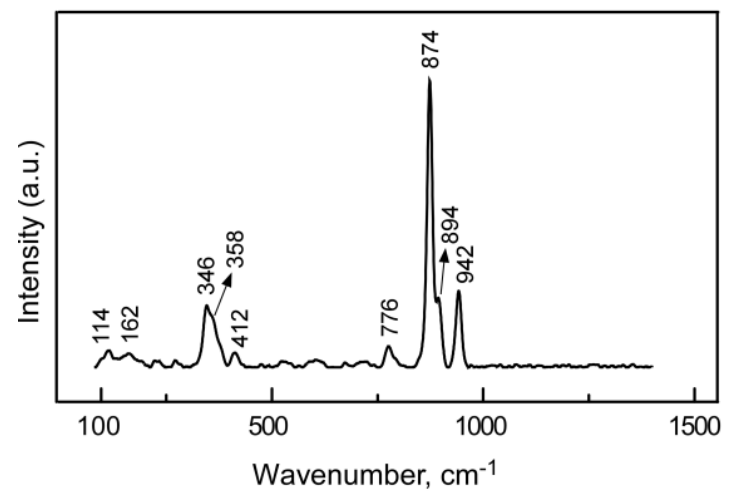

Figure 6. Raman spectrum of the yellow color (Spot 4).

As for the blue, the Raman spectra performed on the Spot 5 showed the use of ultramarine blue, which is a three-dimensional aluminosilicate complex with a sodalite structure containing sodium ions and sulfur groups $\left((\mathrm{Na}, \mathrm{Ca})_{8}\left(\mathrm{AlSiO}_{4}\right)_{6}\left(\mathrm{O}, \mathrm{S}, \mathrm{SO}_{4}\right)_{1-2}\right) \quad(3,25,32) . \quad$ The Raman spectra of the ultramarine blue obtained have bands at 268 (vw) 375 (w), 549 (vs), 584 (sh), 1096 (vw), cm-1 as shown in Figure 7(34-36). The elements regarding the underlying green color, Fe, $\mathrm{Pb}, \mathrm{Cr}, \mathrm{Ba}$ and $\mathrm{S}$, were also detected in XRF spectra.

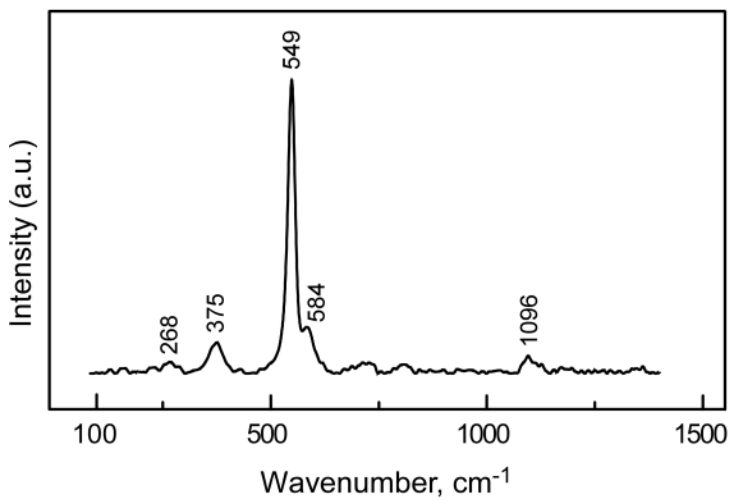

Figure 7. Raman spectrum of the blue color (Spot $5)$.

The Raman analysis of the black color (Spot 2) have given the spectra of a carbon-based black pigment distinguished by two broad bands at around 1320 and $1580 \mathrm{~cm}^{-1}$ as shown in Figure 8 $(37,38)$. On the other hand, the detection of $\mathrm{Ca}$ and $P$ in XRF spectra, can be associated with the presence of bone black. 


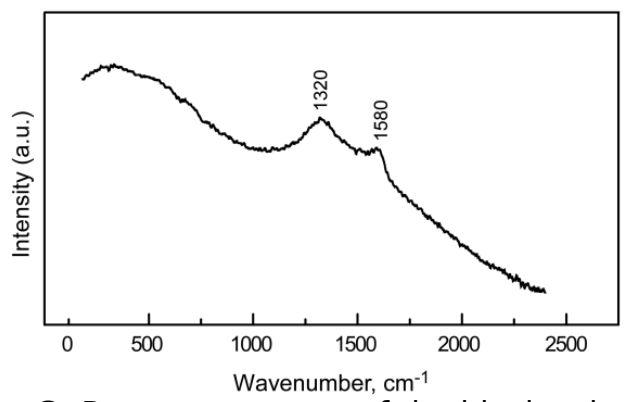

Figure 8. Raman spectrum of the black color (Spot
For the red color (Spot 3), no useful Raman spectra could be collected. However, the detection of key elements such as $\mathrm{Cd}$ and Se in XRF spectrum was a clear indication of the presence of cadmium red pigment (CdSe) and allowed us to distinguish the pigment used from that of any other red pigments (Figure 9). It is also worth noting that the result is emphasized the importance of complementary using of the Raman and XRF techniques for identification purposes.

2).

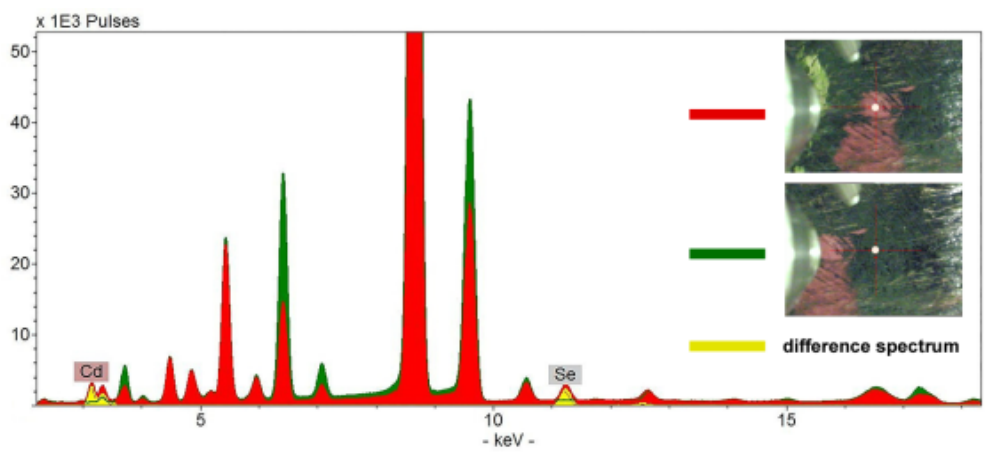

Figure 9. XRF spectra collected from the red and green colors and the difference spectrum.

As regards to artist signature (Spot 7), the color was identified as a mixture of pigments and obtained by adding carbon-based black pigment to hematite $\left(\alpha-\mathrm{Fe}_{2} \mathrm{O}_{3}\right)$ to produce a brown hue. Figure 10 shows the Raman spectrum and the bands at 230 (m-s), 297 (vs), 413 (m-s), 504 (w-m), 617 (m), $676(\mathrm{w}), 801(\mathrm{vw}) \mathrm{cm}^{-1}$ were assigned to the presence of hematite, whereas those at 1318 and $1601 \mathrm{~cm}^{-1}$ were assigned to carbon-based black pigment (37-40). In addition, besides the elements arising from the under layer, $\mathrm{Cd}$ and Se were also detected in XRF spectrum. Thus, the analysis revealed that the occurrence of this brown pigment used for signature consisting of a mixture of at least three different pigment which are hematite, carbon black and cadmium red.

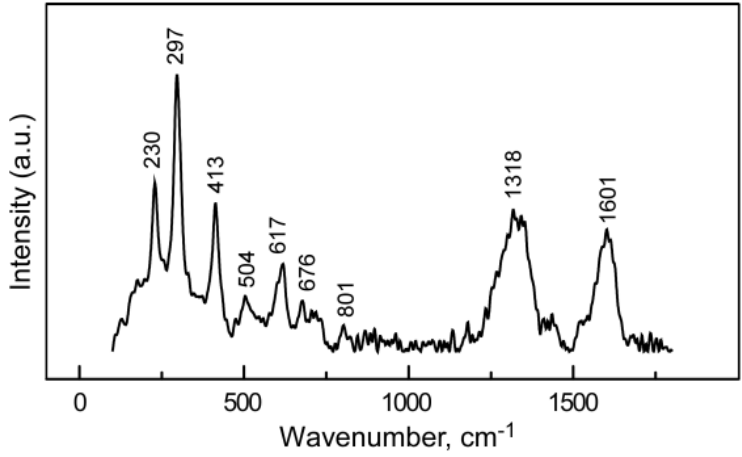

Figure 10. Raman spectrum of the brown signature (Spot 7).

There is another point to take into consideration that zinc was almost always detected in the colors analyzed. It is reported in the literature that treatises from the late medieval period recommended zinc sulfate, also known as zinc vitriol or white vitriol, as driers for varnishes and paints $(41,42)$. The significant amount of zinc detected in this study was most probably incorporated in the form of zinc sulfate which like powdered glass. The detection of sulfur by XRF corroborates the idea of the usage of white vitriol. However, the addition of zinc may also be suggested its addition by manufacturers as a lightening agent(43).

An overview of the study, the measured points and results, is given in Table 1 . 
Table 1. Overview of the measured points, colors, analysis results, identified pigments, and chemical compositions.

\begin{tabular}{|c|c|c|c|c|c|}
\hline $\begin{array}{l}\text { Measuring } \\
\text { Point }\end{array}$ & Color & $\begin{array}{c}\mu-X R F \text { Results } \\
\text { (net peak area } \\
\text { values in } \\
\text { decreasing order) }\end{array}$ & Raman peaks $\left(\mathrm{cm}^{-1}\right)$ & $\begin{array}{l}\text { Chemical } \\
\text { Composition }\end{array}$ & References \\
\hline 1 & White & $\begin{array}{c}\mathrm{Zn}, \mathrm{Pb}, \mathrm{Fe}, \mathrm{Cr}, \mathrm{Ca} \\
\mathrm{Ba}, \mathrm{K}, \mathrm{S}\end{array}$ & $\begin{array}{l}\text { Zinc white: 99(w), 320(vw), } \\
435(v w)\end{array}$ & $\mathrm{ZnO}$ & $(3,25)$ \\
\hline 2 & Black & $\begin{array}{c}\mathrm{Zn}, \mathrm{Pb}, \mathrm{Fe}, \mathrm{Ca}, \mathrm{Cr} \\
\mathrm{Ba}, \mathrm{K}, \mathrm{S}, \mathrm{P} \\
\end{array}$ & $\begin{array}{l}\text { Carbon-based black: } \\
1320(\mathrm{br}), 1580(\mathrm{br})\end{array}$ & $\begin{array}{l}\text { carbon-based } \\
\text { black }\end{array}$ & $(37-40)$ \\
\hline 3 & Red & $\begin{array}{l}\mathrm{Zn}, \mathrm{Cr}, \mathrm{Fe}, \mathrm{Ba}, \mathrm{Pb} \\
\mathrm{Se}, \mathrm{Cd}, \mathrm{Ca}, \mathrm{Sr}, \mathrm{S}\end{array}$ & 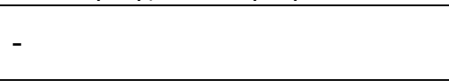 & $\mathrm{CdSe}$ & \\
\hline 4 & Yellow & $\begin{array}{c}\mathrm{Zn}, \mathrm{Cr}, \mathrm{K}, \mathrm{Sr}, \mathrm{Pb}, \mathrm{Fe}, \\
\mathrm{S}, \mathrm{Ba}\end{array}$ & $\begin{array}{l}\text { Zinc yellow: 114(vw), } \\
\text { 162(vw), 346(w-m), } \\
\text { 358(sh), 412(vw), 776(w), } \\
\text { 874(vs), 894(sh), 942(m) }\end{array}$ & $\begin{array}{l}\mathrm{K}_{2} \mathrm{O} \cdot 4 \mathrm{ZnCrO}_{4} \cdot 3 \mathrm{H}_{2} \mathrm{O} \\
\text { and } \mathrm{SrCrO}_{4}(?)\end{array}$ & $(25,27,30)$ \\
\hline 5 & Blue & $\begin{array}{l}\mathrm{Zn}, \mathrm{Fe}, \mathrm{Cr}, \mathrm{Pb}, \mathrm{Ca} \\
\mathrm{Ba}, \mathrm{S}, \mathrm{K}, \mathrm{Sr}, \mathrm{Si}\end{array}$ & $\begin{array}{l}\text { Ultramarine: 268(vw), } \\
\text { 375(w), 549(vs), 584(sh), } \\
\text { 1096(vw) }\end{array}$ & $\mathrm{Na}_{7} \mathrm{Al}_{6} \mathrm{Si}_{6} \mathrm{O}_{24} \mathrm{~S}_{3}$ & $(34-36)$ \\
\hline 6 & Green & $\begin{array}{c}\mathrm{Zn}, \mathrm{Pb}, \mathrm{Ca}, \mathrm{Ba}, \mathrm{Cr} \\
\mathrm{Fe}, \mathrm{Sr}, \mathrm{S}\end{array}$ & $\begin{array}{l}\text { Prussian blue: } 277(w-m), \\
534(w-m), 2091(m), \\
2153(v s) \\
\text { Chrome yellow: } 841(w) \\
\text { Barite: } 987(w)\end{array}$ & $\begin{array}{l}\mathrm{Fe}_{7} \mathrm{C}_{18} \mathrm{~N}_{18} \\
\mathrm{PbCrO}_{4} \\
\mathrm{BaSO}_{4}\end{array}$ & $(24,25)$ \\
\hline 7 & $\begin{array}{l}\text { Signature } \\
\text { (Brown) }\end{array}$ & $\begin{array}{l}\mathrm{Zn}, \mathrm{Fe}, \mathrm{Cr}, \mathrm{Ca}, \mathrm{Ba} \\
\mathrm{Pb}, \mathrm{Cd}, \mathrm{Sr}, \mathrm{S}, \mathrm{Se}\end{array}$ & $\begin{array}{l}\text { Hematite: } 230(\mathrm{~m}-\mathrm{s}) \text {, } \\
\text { 297(vs), 413(m-s), 504(w- } \\
\mathrm{m}), 617(\mathrm{~m}), 676(\mathrm{w}) \\
\text { 801(vw) } \\
\text { Carbon-based black: } \\
1318(\mathrm{br}), 1601(\mathrm{br})\end{array}$ & $\begin{array}{c}\alpha-\mathrm{Fe}_{2} \mathrm{O}_{3}, \mathrm{CdSe}, \text { and } \\
\text { carbon-based } \\
\text { black }\end{array}$ & $(37-40)$ \\
\hline
\end{tabular}




\section{CONCLUSIONS}

The results of the present study once again emphasize the great potential of the complementary use of $\mu$-XRF and Raman spectroscopy and the pigments used by ibrahim Çallı were successfully determined. The painter's palette includes zinc white, zinc yellow, chrome yellow, strontium yellow, ultramarine, Prussian blue, hematite, cadmium red, barite, and carbonbased black pigments.

The knowledge of his palette plays an substantial contribution to the knowledge of the pigments used in 20th century Turkish painting. In addition, one of the most important characteristic of this work was to be the first to investigate a Turkish painting non-destructively. Nevertheless, Çallı's paintings will continue to be analyzed to create an extensive database.

\section{ACKNOWLEDGMENT}

The authors would like to thank Ijpek-Ahmet Merey for allowing the investigation of the precious painting belonging their collection.

\section{REFERENCES}

1. Fotakis, C., Anglos, D., Zafiropulos, V., Georgiou, S., Tornari V. Lasers in the Preservation of Cultural Heritage: Principles and Applications. CRC Press. 2006.

2. Messina, G., Santangelo S. GNSR 2001: State of Art and Future Development in Raman Spectroscopy and Related Techniques. CRC Press. 2001. 290 p.

3. Burgio L, Clark RJH. Library of FT-Raman spectra of pigments, minerals, pigment media and varnishes, and supplement to existing library of Raman spectra of pigments with visible excitation. Vol. 57, Spectrochimica Acta - Part A: Molecular and Biomolecular Spectroscopy. 2001. 1491-1521 p.

4. Best SP, Clark RJH, Withnall R. Nondestructive pigment analysis of artefacts by Raman microscopy. Endeavour. 1992;16(2):66-73.

5. Chalmers JM, Edwards HGM, Hargreaves MD. Infrared and Raman spectroscopy in Forensic Science. Wiley; 2012.

6. Clark RJH. Raman microscopy: Application to the identification of pigments on medieval manuscripts. Chem Soc Rev. 1995;24(3):187-96.

7. Clark RJH. Pigment identification on medieval manuscripts by Raman microscopy. J Mol Struct. 1995;347:417-27.

8. Burgio L, Ciomartan DA, Clark RJH. Pigment identification on medieval manuscripts, paintings and other artefacts by Raman microscopy: Applications to the study of three German manuscripts. J Mol Struct. 1997;405(1):1-11.

9. Jurado-López A, Demko O, Clark RJH, Jacobs D. Analysis of the palette of a precious 16th century illuminated Turkish manuscript by Raman microscopy. J Raman Spectrosc. 2004;35(2):11924.

10. Cazzanelli E, Platania E, De Santo G, Fasanella A, Castriota M. Micro-spectroscopic Raman investigation on the canvas oil painting "Rebecca at the well" of Neapolitan anonymous. J Raman Spectrosc. 2012;43(11):1694-8.

11. Antunes V, Candeias A, Mirão J, Carvalho $M L$, Dias CB, Manhita A, et al. Analytical characterization of the palette and painting techniques of Jorge Afonso, the great 16th century Master of Lisbon painting workshop. Spectrochim Acta - Part A Mol Biomol Spectrosc. 2018;193:26475. Available from:https://doi.org/10.1016/j.saa.2017.12.027

12. Cristina L. Aibeo, Stien Goffin, Olivier Schalm, Geert van der Snickt, Nathalie Laquiere, Peter Eyskens KJ. Micro-Raman analysis for the identification of pigments from 19th and 20th century paintings. J Raman Spectrosc. 2008;39(May):1091-8. Available from: $10.1002 / j$ rs. 1990

13. Damjanović L, Gajić-Kvaščev M, Durdević J, Andrić V, Marić-Stojanović M, Lazić T, et al. The characterization of canvas painting by the Serbian artist Milo Milunović using X-ray fluorescence, micro-Raman and FTIR spectroscopy. Radiat Phys Chem. 2015;115:135-42.

14. Ricci C, Borgia I, Brunetti BG, Miliani C, Sgamellotti A, Seccaroni C, et al. The Perugino's palette: Integration of an extended in situ XRF study by Raman spectroscopy. J Raman Spectrosc. 2004;35(8-9):616-21.

15. Artesani A, Ghirardello M, Mosca S, Nevin A, Valentini G, Comelli D. Combined photoluminescence and Raman microscopy for the identification of modern pigments: explanatory examples on cross-sections from Russian avantgarde paintings. Herit Sci. 2019;7(1):1-13.

Available from: https://doi.org/10.1186/s40494019-0258-x

16. Giorgi L, Nevin A, Nodari L, Comelli D, Alberti R, Gironda M, et al. In-situ technical study of modern paintings part 1: The evolution of artistic materials and painting techniques in ten paintings from 1889 to 1940 by Alessandro Milesi (18561945). Spectrochim Acta - Part A Mol Biomol Spectrosc. 2019;219:530-8. Available from: https:// doi.org/10.1016/j.saa.2019.04.083

17. Vermeulen M, Saverwyns S, Coudray A, Janssens K, Sanyova J. Identification by Raman spectroscopy of pararealgar as a starting material in the synthesis of amorphous arsenic sulfide pigments. Dye Pigment. 2018;149(October 
2017):290-7.

18. Akyuz S, Akyuz T, Emre G, Gulec A, Basaran S. Pigment analyses of a portrait and paint box of Turkish artist Feyhaman Duran (1886-1970): The EDXRF, FT-IR and micro Raman spectroscopic studies. Spectrochim Acta - Part A Mol Biomol Spectrosc. 2012;89:74-81. Available from: http://dx.doi.org/10.1016/j.saa.2011.12.046

19. Yaban NT. Environment of Culture and Art in the Ottoman Empire in 19th Century. Online J Sci Technol. 2018;8(2):71-8.

20. Shaw WMK. Ottoman painting: reflections of Western art from the Ottoman Empire to the Turkish Republic. IB Tauris Publishers. 2010. 208 p.

21. Gültekin G. Western Trends in the Turkish Art of Painting.pdf. Ankara: T.C. Ziraat Bankası Cultural and Art Activities, Ajans Türk Publishing\&Printing Co. Inc.; 1992. 216 p.

22. Veronika Košařová, David Hradil, Janka Hradilová, Zdeňka Čermáková, Ivan Němec MS. The efficiency of micro-Raman spectroscopy in the analysis of complicated mixtures in modern paints: Munch's and Kupka's paintings under study. Spectrochim Acta Part A Mol Biomol Spectrosc. 2016;156:36-46.

23. Marinho JZ, Romeiro FC, Lemos SCS, Motta F V., Riccardi CS, Li MS, et al. Urea-based synthesis of zinc oxide nanostructures at low temperature. J Nanomater. 2012;2012.

24. Rosi F, Miliani C, Borgia I, Brunetti B, Sgamellotti A. Identification of nineteenth century blue and green pigments by in situ x-ray fluorescence and micro-Raman spectroscopy. J Raman Spectrosc. 2004;35(8-9):610-5.

25. Bell IM, Clark RJH, Gibbs PJ. Raman spectroscopic library of natural and synthetic pigments (pre- 1850 AD). Spectrochim Acta - Part A Mol Biomol Spectrosc. 1997;53(12):2159-79.

26. Grim DM, Allison J. Identification of colorants as used in watercolor and oil paintings by UV laser desorption mass spectrometry. Int J Mass Spectrom. 2003;222(1-3):85-99.

27. Edwards HGM. Analytical raman spectroscopic discrimination between yellow pigments of the renaissance. Spectrochim Acta Part A Mol Biomol Spectrosc. 2011;80(1):14-20. Available from:

http://dx.doi.org/10.1016/j.saa.2010.12.023

28. Li XL, Sun CJ, Luo L Bin, He Y. Nondestructive detection of lead chrome green in tea by Raman spectroscopy. Sci Rep. 2015;5:1-9. Available from:http://dx.doi.org/10.1038/srep15729
29. Gautier G, Bezur A, Muir K, Casadio F, Fiedler I. Chemical fingerprinting of ready-mixed house paints of relevance to artistic production in the first half of the twentieth century. Part I: Inorganic and organic pigments. Appl Spectrosc. 2009;63(6):597-603.

30. Correia AM, Clark RJH, Ribeiro MIM, Duarte MLTS. Pigment study by Raman microscopy of 23 paintings by the Portuguese artist Henrique Pousão (1859-1884). J Raman Spectrosc.

2007;38(11):1390-405.

31. Simonsen KP, Christiansen MB, Vinum MG, Sanyova J, Bendix J. Single crystal X-ray structure of the artists' pigment zinc yellow. J Mol Struct. 2017;1141:322-7. Available from: http://dx.doi.org/ 10.1016/j.molstruc.2017.03.108

32. Nicholas Eastaugh, Valentine Walsh, Tracey Chaplin RS. Pigment Compendium. A Dictionary and Optical Microscopy of Historical Pigments. Butterworth-Heinemann. 2008.

33. Feller RL, editor. Artists' Pigments: A Handbook of Their History and Characteristics. Volume 1. Oxford University Press; 1986.

34. Osticioli I, Mendes NFC, Nevin A, Gil FPSC, Becucci M, Castellucci E. Analysis of natural and artificial ultramarine blue pigments using laser induced breakdown and pulsed Raman spectroscopy, statistical analysis and light microscopy. Spectrochim Acta - Part A Mol Biomol Spectrosc. 2009;73(3):525-31.

35. Frausto-Reyes C, Ortiz-Morales M, BujdudPérez JM, Magaña-Cota GE, Mejía-Falcón R. Raman spectroscopy for the identification of pigments and color measurement in Dugès watercolors. Spectrochim Acta - Part A Mol Biomol Spectrosc. 2009;74(5):1275-9.

36. Colomban P. Lapis lazuli as unexpected blue pigment in Iranian Lâjvardina ceramics. J Raman Spectrosc. 2003;34(6):420-3.

37. Tomasini EP, Halac EB, Reinoso M, Di Liscia EJ, Maier MS. Micro-Raman spectroscopy of carbonbased black pigments. J Raman Spectrosc.

2012;43(11):1671-5.

38. Coccato A, Jehlicka J, Moens L, Vandenabeele P. Raman spectroscopy for the investigation of carbon-based black pigments. J Raman Spectrosc. 2015;46(10):1003-15.

39. Pięta E, Proniewicz E, Szmelter-Fausek B, Olszewska-wietlik J, Proniewicz LM. Pigment characterization of important golden age panel paintings of the 17th century. Spectrochim Acta Part A Mol Biomol Spectrosc. 2015;136:594-600. 
40. Lauridsen CB, Sanyova J, Simonsen KP. Raman analysis of complex pigment mixtures in 20th century metal knight shields of the Order of the Elephant. Spectrochim Acta - Part A Mol Biomol Spectrosc. 2015;150:54-62. Available from: http://dx.doi.org/10.1016/j.saa.2015.04.117

41. O'Donoghue E, Romero R, Dik loris. French eighteenth-century painting techniques. Stud Conserv. 1998;43(sup1):185-9.
42. Burgio L, Clark RJH, Hark RR. Raman microscopy and $\mathrm{x}$-ray fluorescence analysis of pigments on medieval and Renaissance Italian manuscript cuttings. Proc Natl Acad Sci U S A. 2010;107(13):5726-31.

43. Osmond $\mathrm{G}$, keune $\mathrm{K}$, Boon J. A study of zinc soap aggregates in a late 19th century painting by R.G. Rivers at the Queensland Art Gallery. AICCM Bull. 2005;29(1):37-46. 
